\title{
Hjelp til forskerselvhjelp
}

Hva trenger du for å etablere ditt eget, private forskningslaboratorium? Og hvilken familiesituasjon er best for deg som ung forsker? Det er mange sider av livet som forsker som skal fungere. Mesterne har forsøkt å gi deg råd.

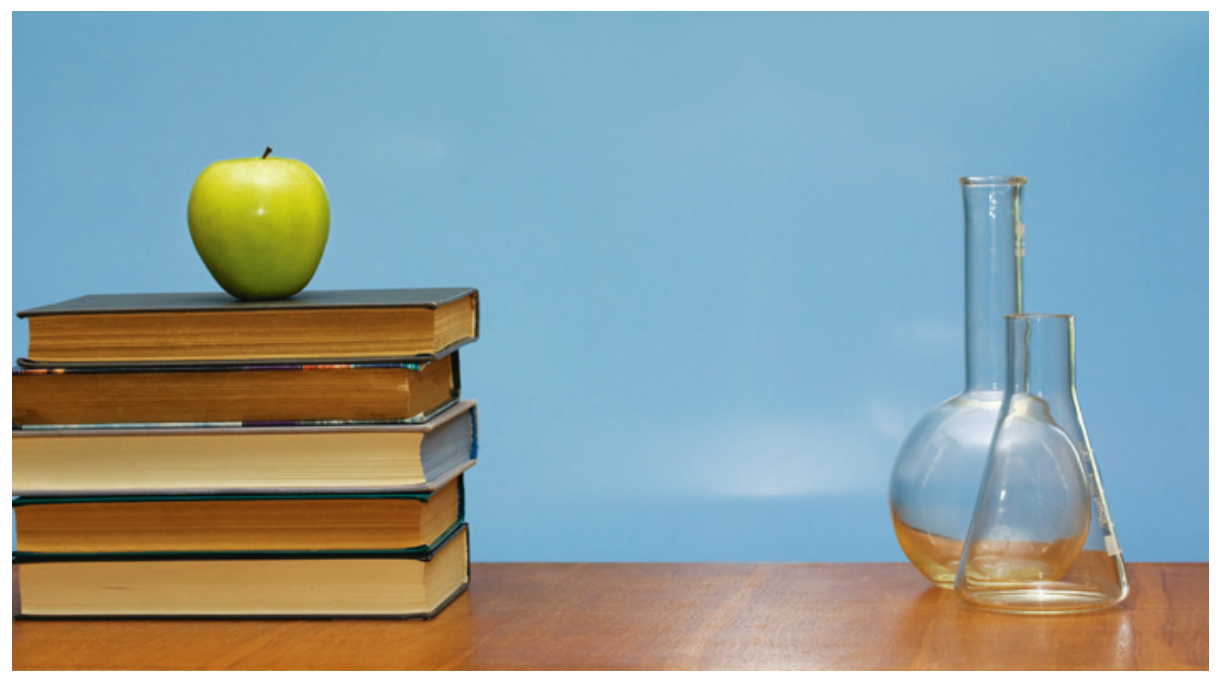

\section{Kristin Viste}

Kristin.viste@legeforeningen.no

Kristin Viste har doktorgrad i cellulær biokjemi. Hun jobber som lege i spesialisering innen medisinsk biokjemi og er medisinsk redaktør i Tidsskriftet

\section{PUBLISERT I BLOGGEN}

(b) 16.8 .2013

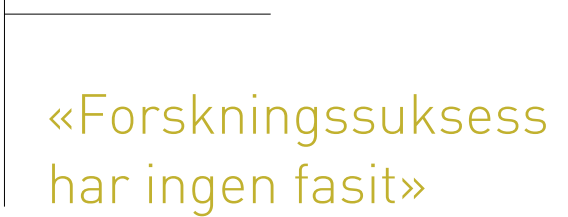

Illustrasjonsfoto Thinkstock

De erfarne vil alltid forsøke å gi råd til nykommerne. Selvhjelpslitteraturen har derfor eksistert siden antikken. Gitt at sjangeren ikke fikk sitt store oppsving før på slutten av forrige århundre, er det imponerende at den første selvhjelpsboken for unge forskere ble utgitt allerede på slutten av 1800-tallet. Santiago Ramón y Cajal er nok mer kjent for sitt bidrag til nevrovitenskapen enn sine råd til unge forskere, men boken Advice for a young investigator er vel verd å få med seg. Cajal gir råd om de fleste aspekter av livet som forsker, fra hvilke personlige egenskaper en god forsker bør ha eller tilegne seg, til hvilken type kone man bør velge. Vel 100 år etter at boken ble gitt ut første gang, er den nå en blanding av historiske kuriositeter og råd som fremdeles er like relevante.

Med Peter B. Medawars bok Advice to a young scientist tar forskerens selvhjelpslitteratur steget til 1970-tallet. Richard Dawkins har beskrevet Medawar som «the wittiest of science writers», og dette bærer boken på 100 lettleste sider preg av. I stedet for å gi råd angående valg av ektefelle gir han råd bl.a. om hvordan valgte ektefelle skal håndtere å ha fått en forsker i hus.
I James D. Watsons bok Avoid boring people-and other lessons from a life in science kan man blant annet lese om hans forsøk på å kurtisere Medawars datter. Informasjon om dette samt eksempelvis prisen på en trikketur da Watson var stipendiat, har muligens betydning kun for spesielt interesserte. Innimellom et overskudd av detaljer analyserer imidlertid Watson hva som brakte ham suksess. Tidvis drukner dessverre disse rådene, og Watson er heller ikke kjent for sin fintfølelse i beskrivelse av medmennesker og situasjoner. Med litt tålmodighet får man et bilde av en fascinerende, dog tidvis ubehøvlet forsker. For dem med begrenset tålmodighet anbefales heller kortversjonen av historien rundt oppdagelsen av DNA - The double helix.

Edward O. Wilson var Watsons samtidige ved Harvard, men der Watson mente det var prematurt å studere noe større enn cellen, ble Wilson verdens ledende ekspert på sosial oppførsel hos maur. I Wilsons 20 Letters to a young scientist finnes anekdoter fra både maurens og forskerens verden, ispedd råd til de helt nyeste av forskerne. Selv om ikke alle veiledere vil applaudere rådet om å gjøre pilotforsøk uten kontroller og uten å skrive ned hva man faktisk har gjort, er boken likevel verd å lese.

Leser man mange nok av selvhjelpsbøkene, oppdager man at de store mesterne ikke nødvendigvis er enige. Mens Wilson hevder at en forsker aldri skal ha ferie, men må ta fri i helgene, mener Watson at man bør jobbe i helgen, men gjerne ta ferie. Mens Cajal anbefaler å lese mye og å lese vidt, anbefaler Medawar å begrense lesingen og heller komme seg i gang med laboratoriearbeid. Forskningssuksess har ingen fasit. Dette er likevel ingen grunn til ikke å la seg more av beretningene fra spennende forskerkarrierer, med mulighet til å plukke opp noen råd. Ofte er det til og med mulig å velge den boken som gir råd om å gjøre det man likevel hadde tenkt å gjøre.

Lenker til alle ovennevnte bøker finner du i utgaven pånett.

Kommentarer til og diskusjoner om innlegget finner du på blogg.tidsskriftet.no Vil du blogge, ta kontakt. 